\title{
The effects of supply chain cooperation on humanitarian relief operations: $A$ case of Cyclone Idai in Zimbabwe
}

\begin{tabular}{|c|c|}
\hline $\begin{array}{l}\text { Authors: } \\
\text { Felix Chari }{ }^{1} \text { @ } \\
\text { Ozwell Muzin } \\
\text { Cawe Novuke } \\
\text { Bethuel S. Ng }\end{array}$ & $\begin{array}{l}\mathrm{da}^{2} \text { (1) } \\
\mathrm{a}^{1} \text { (1) } \\
\mathrm{amu}^{3} \text { (1) }\end{array}$ \\
\hline \multicolumn{2}{|c|}{$\begin{array}{l}\text { Affiliations: } \\
{ }^{1} \text { Department of Governance } \\
\text { and Management, Faculty } \\
\text { of Business Management, } \\
\text { Walter Sisulu University, } \\
\text { East London, South Africa }\end{array}$} \\
\hline $\begin{array}{l}{ }^{2} \text { Department } \\
\text { Chain Manage } \\
\text { Zimbabwe, Ha } \\
\text { Zimbabwe }\end{array}$ & $\begin{array}{l}\text { f Supply } \\
\text { ment, Halo } \\
\text { rare, }\end{array}$ \\
\hline $\begin{array}{l}{ }^{3} \text { Department } \\
\text { Management } \\
\text { Faculty of Hur } \\
\text { Mandela Univ } \\
\text { Elizabeth, Sou }\end{array}$ & $\begin{array}{l}\text { of Public } \\
\text { and Leadership, } \\
\text { nanities, Nelson } \\
\text { ersity, Port } \\
\text { th Africa }\end{array}$ \\
\hline \multicolumn{2}{|c|}{$\begin{array}{l}\text { Corresponding author: } \\
\text { Felix Chari, } \\
\text { charifelix93@gmail.com }\end{array}$} \\
\hline $\begin{array}{l}\text { Dates: } \\
\text { Received: } 14 \text { J } \\
\text { Accepted: } 22 \\
\text { Published: } 11\end{array}$ & $\begin{array}{l}\text { uly } 2020 \\
\text { lan. } 2021 \\
\text { Mar. } 2021\end{array}$ \\
\hline \multicolumn{2}{|c|}{$\begin{array}{l}\text { How to cite this article: } \\
\text { Chari, F., Muzinda, O., } \\
\text { Novukela, C. \& Ngcamu, B.S., } \\
2021 \text {, 'The effects of supply } \\
\text { chain cooperation on } \\
\text { humanitarian relief } \\
\text { operations: A case of Cyclone } \\
\text { Idai in Zimbabwe', Journal of } \\
\text { Transport and Supply Chain } \\
\text { Management } 15(0), \text { a532. } \\
\text { https://doi.org/10.4102/ } \\
\text { jtscm.v15i0.532 }\end{array}$} \\
\hline \multicolumn{2}{|c|}{$\begin{array}{l}\text { Copyright: } \\
\text { ( 2021. The Authors. } \\
\text { Licensee: AOSIS. This work } \\
\text { is licensed under the } \\
\text { Creative Commons } \\
\text { Attribution License. }\end{array}$} \\
\hline \multicolumn{2}{|l|}{ Read online: } \\
\hline 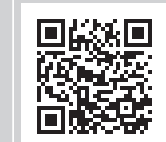 & $\begin{array}{l}\text { Scan this QR } \\
\text { code with your } \\
\text { smart phone or } \\
\text { mobile device } \\
\text { to read online. }\end{array}$ \\
\hline
\end{tabular}

Background: The increased frequency of occurrence and complexity of disasters, the world over, have called for increased cooperation amongst stakeholders to deliver humanitarian aid.

Objectives: This study came as a result of the growing interest focussed on creating and implementing cooperation to facilitate management of supply chain-related activities in the humanitarian sector. This study therefore sought to gain a better understanding of the effectiveness of supply chain cooperation in aid delivery performance variables, specifically in the context of Cyclone Idai humanitarian relief operations in Zimbabwe.

Method: A pragmatic research paradigm was adopted, where the researchers took a mixed approach informed by both quantitative and qualitative research tools.

Results: Findings of this study show a significant and positive impact of humanitarian supply chain (HSC) cooperation in achieving output, resource and flexibility performance in the delivery of aid. These findings will change the shape of humanitarian response to have more cooperation amongst organisations rather than responding as single entities.

Conclusion: This study will therefore contribute to how humanitarian organisations improve their approach to future disasters through cooperation in their supply chain activities. Theoretically, the study will show how supply chain cooperation is key to humanitarian responses, thus improving effectiveness of HSC when put into practice. Policymakers can use these findings to develop a standard framework of how humanitarian organisations should collectively respond to disasters.

Keywords: cyclone; humanitarian logistics; relief operations; supply chain; supply chain cooperation.

\section{Introduction}

The world over, disasters are now much larger, frequent and more complex than before. The Southern African region is not exempted and continues to be impacted by severe and extreme natural disasters, especially weather-related events (Save the Children 2019). The increased frequency of cyclone occurrences has become a pronounced issue in the Southern African region as evidenced by the occurrence of Cyclone Eline in the year 2000, Cyclone Favio in the year 2007, Cyclone Japhet in the year 2002, Cyclone Dineo in the year 2017 and recently Cyclone Idai of 2019 (Mhlanga, Muzingili \& Mpambela 2019). These cyclones result in starvations, hunger, death, economic dilapidation, trade malfunctioning, interrupted distribution networks and environmental destruction calling for humanitarian intervention (The Government Office for Science 2012). Humanitarian responses often involve large numbers of national and international actors who frequently work in the same geographical areas towards achieving the same broader goals. This huge and complicated supply network of diverse actors includes donors, non-governmental organisations (NGOs), government, military, the private sector, philanthropists, the community and suppliers who cooperate in delivering aid to the affected communities (Adem et al. 2018). This study came as a result of an exponentially growing interest amongst authors (Chari \& Ngcamu 2017; Mushanyuri \& Ngcamu 2020; Wankmüller \& Reiner 2020) to evaluate the effects of cooperation as an enabler to facilitate management of supply chain-related activities in the humanitarian sector. It is therefore in these researchers' interest to get a better insight into these disasters to evaluate the effects of humanitarian supply chain (HSC) cooperation on aid delivery performance variables, specifically in the context of Cyclone Idai humanitarian relief operations in Zimbabwe. 
Tropical Cyclone Idai, the worst cyclone to hit the Southern Hemisphere, caused a catastrophic damage to the infrastructure in Madagascar, Mozambique, Zimbabwe and Malawi, leaving more than 1300 people dead, 3 million people in need of emergency assistance and many more missing (European Commission 2019; UNICEF 2019). The cyclone shook both private sector and HSCs in Mozambique, extending inland to some provinces and districts of Malawi and Zimbabwe. Zimbabwe was hit leaving behind a death toll of over 268 people and appealing for international and domestic organisations to help in disaster relief (UNICEF 2019). Humanitarian relief operations are characterised by numerous supply chain uncertainties that need to be mitigated during catastrophic events in the affected countries. During and after Cyclone Idai, supply chain risks such as infrastructure, economic and social risks played a big role in interrupting the delivery of basic services such as water and electricity. These interruptions adversely affected the responsiveness of different organisations to disaster management excellence in the affected countries (Chari, Ngcamu \& Novukela 2020). Wankmüller and Reiner (2020) noted that cooperation in relief supply chain management (RSCM) has the potential to address these risks and achieve HSC objectives. In related studies, Chari et al. (2020) established the risk factors in supply chain in Zimbabwe. However, there is lack of studies that have established the effects of HSC cooperation on performance objectives of humanitarian organisations. This study therefore addresses the following overall research objective: To establish the effects of HSC cooperation on output, resource and flexibility performance. This will help to examine the different ways in which organisations work together in disaster preparedness and response and how this contributes to the performance variables of HSC.

The remaining part of this article is organised as follows. The second section reviews the literature on HSC cooperation and humanitarian logistics performance variables of output, resource and flexibility and the developed hypotheses. The third section focusses on research methods whilst the fourth section presents and discusses the results of the study. The fifth section presents conclusions and recommendations of the study. Finally, the sixth section gives implications of results on theory and practice, limitations of the study and recommendations for further studies.

\section{Literature review}

This section covers the literature on HSC, cooperation and risks as well as a brief overview of HSC performance variables.

\section{Humanitarian supply chains, risks and cooperation}

Humanitarian supply chain involves a set of logistical activities carried out during disaster response operations with the aim of attaining coordinated logistics excellence (Herrmann 2007). It consists of a network of interaction between donors, governments, international and locally based agencies, suppliers and numerous other stakeholders that coordinate and oversee the flow of supplies, services and information for responding to beneficiary needs (Chari \& Ngcamu 2017). These activities involve a task of transporting large volumes of supplies and materials that are essential during disaster relief response (Tatham \& Pettit 2010). The main challenge after a disaster has occurred is to fulfil the mandate of RSCM team for getting the right amount of resources to the place of disaster to cover the initial needs of survivors in less amount of time.

However, humanitarian relief operations have been hampered by supply chain risks. The world currently faces new and increasingly volatile disaster-driven risks such as communication, economy, transport and politics (Mushanyuri \& Ngcamu 2020).

This study is hitched on the social exchange theory. The concept of social exchange has suggested that interdependence reduces risks and encourages cooperation to achieve successful logistics relationships (Lambe, Wittmann \& Spekman 2001; Pai \& Yeh 2015). In this regard, the study will focus on a variety of ways that different organisations work together in preparedness, disaster response and recovery stages of disaster management at a country level. It considers bilateral relationships between organisations, as well as relationships amongst multiple organisations that work together in humanitarian relief operations. To overcome risks and to find new ways to explain relational exchange, researchers of inter-organisational relationships have recently drawn attention increasingly on social exchange theory (Lambe et al. 2001). Cooperation is gaining momentum on the importance of understanding successful humanitarian relationships (Wankmuller \& Reiner 2019). The number of organisations involved in humanitarian relief work is growing, thus creating new complexity.

Most hazards that require international assistance are too large for any one organisation to address. By working together, organisations can cover broad geographical areas and address a variety of sectoral needs. Working in clusters and other coordination bodies has been shown to be an effective way to avoid geographical and sectoral duplication and to decrease the gaps in a response (Schulz \& Blecken 2010). This high complexity and volatility of disasters in recent decades have called for public, nonprofit and private organisations to partner in disaster response. The diversity of actors operating along relief chains is extremely high depending on the magnitude or severity of disasters. Examples include hundreds of organisations in Haiti after the 2010 earthquake and more than 700 different NGOs after the Tsunami in 2004 (Nolte \& Boenigk 2013). Whilst there are different forms of inter-organisational partnering that can be represented on a continuum of increased inter-organisational embeddedness in partnering activities, which are communication, cooperation, coordination and collaboration (Schulz \& Blecken 2010), this study focusses on cooperation. 
Cooperation refers to short-term, often informal and voluntary, relationships between NGOs amongst other humanitarian actors in the preparedness and response phases to disasters characterised by low levels of intensity and risk (Brown \& Keast 2003; McMaster \& Baber 2012; Ödlund 2010; Schulz \& Blecken 2010).

Cooperation amongst NGOs or other humanitarian organisations, the military, government, philanthropists and private business is increasingly needed in the HSCs despite each part's experiences (Van Wassenhove 2006). Cooperation incorporates working together, alongside other NGOs towards a common mission, and sharing information to provide humanitarian assistance to disaster victims (Chandes \& Pache 2019; Schulz \& Blecken 2010). Cooperative coordination can involve a variety of activities, from agreeing to follow common guidelines to gathering information through joint assessments (Martin 2016). The main reasons to cooperate with other organisations during an emergency are to work towards a common mission and to avoid programme duplication (Kapucu 2006). They are more formalised than just sharing information and require organisations to make more of a commitment to contributing to the process and adjusting their own plans to fit any group's decision. However, cooperative coordination still leaves organisations with a very high degree of autonomy. Whilst organisations are more likely to hold one another to account for, agreements are generally non-binding and continually negotiable. They also tend to affect only some aspects of work, such as location or technical aspects of programming, leaving organisations free to work as they wish in other respects.

Empirical studies on humanitarian response to Tsunami 2004 indicated that cooperation experiences were positive in output, resource and flexibility performance. It however demonstrated that cooperation was more successful in meeting needs on an ad hoc basis but less effective in the meeting of ongoing needs. The primary reason being that whilst many organisations reported cooperation with other humanitarian organisations in the delivery of relief, the results of various cooperation requirements were mixed as organisations struggled to get balance of their internal operations requirements with desire to work with others (Fritz Institute 2005).

\section{Humanitarian supply chain performance}

Measuring performance in the private sector is more straightforward because financial metrics are used, which in most cases are clear and accessible indicators of performance (Government of India 2009).

Organisational performance is the final achievement of an organisation and constitutes various factors such as the attainment of certain targets that include period of time efficiency and effectiveness (Almatrooshi, Kumar \& Farouk 2016; Iyer 2011). Organisational performance is the measure of an organisation's or individual's productivity in terms of profit, quality product, market share, expansion and survival.
It is used to make adjustments on accomplished goals more efficiently and effectively (Narasimhan \& Jayaram 1998).

However, unlike commercial supply chains, Pettit and Baresford (2009) identified relief output performance in terms of saving lives and flexibility as key success factors in HSC. Pettit and Baresford (2009) further argue that efficiency, in terms of minimising resources used by supply chain actors, is one of the main criteria of HSC network design especially in sensitive phases such as the preparedness and response phase. The subsections here discuss details of the output, flexibility and resource performance variables.

\section{Output performance}

Output performance metrics measure the effectiveness with which supply chains are able to supply (Pettit \& Baresford 2009). Effectiveness is defined as the extent to which customer requirements are met, as opposed to efficiency, which measure how economically the resources are utilised when providing a given level of effectiveness (Neely, Gregory \& Platts 1995). Ideally, output performance metrics correspond to an organisation's strategic goals and to its customers' goals and values (Beamon 1999). Examples of output metrics include per cent on-time deliveries and customer responsiveness, manufacturing lead time, the number of back-orders or stock-outs per cycle, quality and the quantity of final product produced. In HSC management, output performance metrics include relief chain response time and the number of relief items supplied to aid recipients (Beamon $\&$ Balcik 2008). Therefore, shorter lead times and high supply availability and resilience are highly desirable in relief response supply chain management (Beamon \& Balcik 2008). According to Pettiti and Beresford (2009), the success of humanitarian response heavily depends on the effectiveness of the supply chain, both inbound and outbound. However, unlike commercial supply chains where the main objective is to achieve profitability, HSC management aims at being more responsive to meet the demand desperately needed. Many authors (Beamon \& Balcik 2008; Hedlund \& Clarke 2011; Pettiti \& Beresford 2009) have advocated for cooperation amongst humanitarian actors as the panacea to improve effectiveness by increasing the speed of response and availability of relief aid. For example, international NGOs working with national NGOs that are closer to the ground become more effective (Hedlund \& Clarke 2011). The fact of working together creates higher levels of communication and so makes more information available to humanitarian actors, allowing them to make more informed decisions. It is therefore hypothesised that:

$\mathrm{H}_{1}$ : Humanitarian supply chain cooperation significantly improves supply chain effectiveness.

\section{Resource performance}

The resource performance metrics measure the level of resources used to meet the system's objectives (Beamon \& Balcik 2008). Resources are generally measured in terms of the minimum quantity requirements or a composite efficiency 
metric and are explicitly tied to flexibility and output (Beamon 1999). Examples of resource performance metrics include the number of person-hours required for an activity, inventory holding costs and heating and air-conditioning costs. In HSC management, efficiency metrics are dominated by three costs: the cost of supplies, distribution costs and inventory-holding costs. Another efficiency indicator in HSC is delivery time that measures how long it takes for an item to be delivered after a donor has pledged to donate it. Cooperation amongst humanitarian actors should mean more cost-effective logistics operations and improved operational efficiency to benefit aid recipients (Kovacs \& Spens 2017). According to Simatupang and Sridharan (2015) and Whipple and Rusell (2007), cooperation improved networks and can result in improved delivery and customer's satisfaction. Barringer and Harrison (2000) and Whipple and Russell (2007) also argued that the network and relationships would improve on time of deliveries. Cooperation between international actors and local NGOs often achieves decreased project costs, making provision of aid cheaper (Ramalingam, Gray \& Cerruti 2013). Cooperation in procurement and service activities can reduce duplication and achieve economies of scale. A good example of this is the coordinated provision of services through the Logistics Cluster (Majewski et al. 2012). It is therefore hypothesised that:

$\mathrm{H}_{2}$ : Humanitarian supply chain cooperation significantly improves supply chain resource efficiency.

\section{Flexibility}

As a result of high environmental uncertainty, it is of essence that organisations must not only build resilience but also build supply chain flexibility (Kamalahmadi \& Mellat-Parast 2016). Flexibility metrics, as applied to supply chain analysis, describe the range of possible operating conditions that are profitably achievable by the chain (Beamon 1999; Muntaka, Haruna \& Mensah 2017). Flexibility is one of the critical elements in HSC management because of greater demand uncertainties and the need to save human health and life. Examples of flexibility metrics in HSC include the number of aid units that a plant can deliver in given hours and the shortest delivery lead time that the distribution centre can profitably achieve. There is a potential for cooperation amongst humanitarian organisation to enhance supply chain flexibility (Schulz \& Blecken 2010). It is therefore hypothesised that:

$\mathrm{H}_{3}$ : Humanitarian supply chain cooperation significantly improves supply chain flexibility.

\section{Methodology}

This study used pragmatic paradigm where the researchers adopted a mixed approach informed by both quantitative and qualitative research tools presented in Appendix 1. The use of a mixed approach to data collection ensured reliability and validity of research instruments, thereby increasing confidence in the findings (Polit et al. 2001). In an attempt to address the research objectives, data were gathered by using a questionnaire survey of humanitarian actors made up of international NGOs and United Nations (UN) agencies. Some of the questionnaires were repeatedly distributed to the same participants to test reliability through checking consistency on their answers (Heale \& Twycross 2015).

Cronbach's alpha coefficients were calculated to ascertain the reliability of the questionnaire and any values above 0.70 are acceptable implying that the instrument was reliable (Walliman 2011). A sample size of 22 humanitarian organisations was randomly selected from 27 humanitarian actors who participated in the relief operations. Simple random sampling yielded an accurate representation of the population making generalisations to larger groups possible (Sekaran \& Bourgie 2016). A further 10 respondents were purposively drawn from the 22 humanitarian organisations, who had answered the questionnaire, to respond to an interview questions. The interviews were limited to 10 as the researchers observed that further data collection was unnecessary because of data saturation as interviewers kept getting similar themes over and over again (Bryman 2012; Walliman 2011).

The interviews enabled the researchers to have an in-depth understating of how HSC cooperation in Cyclone Idai relief operations impacted on performance in the humanitarian aid response sector.

The use of triangulation also enabled the researcher to accurately distinguish the correct information amongst many pieces of information provided (Sekaran \& Bourgie 2016). Issues with regard to confidentiality were honoured by the researchers as all confidential information was used for the stated and required purposes only (Walliman 2011). Furthermore, the researchers made it clear to the respondents that they had an unconditional right to refuse, to participate and to withdraw from the study at any time to ensure that the data collection involved only those who were genuinely willing to take part and prepared to offer data freely.

Hypotheses $\mathrm{H}_{1}, \mathrm{H}_{2}$ and $\mathrm{H}_{3}$ test the effect of cooperation on performance metrics of output, efficiency and flexibility, respectively. To understand the effect of cooperation on performance variables the following ordinary least square (OLS) regression models were proposed:

$\mathrm{Y}_{1 \mathrm{I}=} \alpha_{1}+\beta_{1}$ Cooperation $+\mu$

[Eqn 1]

where $Y_{1 \mathrm{I}}$ represents the output performance metric. The variable cooperation represents an index of various forms of cooperation by HSC stakeholders, $\mu$ is the residual term and $\alpha_{1}$ is the constant. It equals the value of $Y_{11}$ when cooperation is 0 , and $\beta_{1}$ represents how much $Y_{1 I}$ changes for each oneunit change in cooperation:

$\mathrm{Y}_{2 \mathrm{~J}=\alpha_{2}}+\beta_{2}$ Cooperation $+\mu$

[Eqn 2]

where $Y_{2 J}$ represents the resource performance metric. The variable cooperation again represents an index of various forms of cooperation by HSC stakeholders and $\mu$ is the 
residual term. Whilst $\alpha_{2}$ is the constant, it equals the value of $Y_{2 J}$ when cooperation is 0 , and $\beta_{2}$ represents how much $Y_{2 J}$ changes for each one-unit change in cooperation:

$\mathrm{Y}_{3 \mathrm{~K}}=\alpha_{3}+\beta_{3}$ Cooperation $+\mu$

[Eqn 3]

where $\mathrm{Y}_{3 \mathrm{~K}}$ is the flexibility performance metric. The variable cooperation is an index of various forms of cooperation by HSC stakeholders, $\mu$ is the residual term and $\alpha_{3}$ is the constant. It equals the value of $Y_{3 K}$ when cooperation is 0 , and $\beta_{3}$ represents how much $Y_{3 \mathrm{~K}}$ changes for each one-unit change in cooperation.

Ordinary least square regression analysis was conducted for quantitative data by using STATA Version 12 whilst qualitative data were analysed by using NVivo to identify themes (forms of cooperation and performance metrics) emerging from the data and consequently identify relationships between themes (Taylor-Powell \& Renner 2003). The results were presented in tabular form for quantitative results whilst qualitative results were presented in vignettes.

\section{Ethical considerations}

This article followed all ethical standards for research without direct contact with human and animal subjects.

\section{Results and discussion Reliability statistics for the questionnaire}

The reliability coefficients for Likert scales in the questionnaire are presented in Table 1.

Results in Table 1 show that all the variables on the questionnaire have Cronbach's alpha values above 0.7 , which is an acceptable level of reliability justifying the reliability of the research instrument (Walliman 2011).

\section{Inferential results}

The results of the OLS regression estimation of Equations (1-3) are presented in Table 2. The OLS estimation shows how HSC cooperation, used in Cyclone Idai relief operations, impacted on performance variables.

The results are analysed, interpreted and discussed in subsequent subsections.

\section{Impact of humanitarian supply chain cooperation in achieving output performance}

Table 2 shows the impact of HSC cooperation in achieving output performance. According to column 1 of Table 2, there is a positive significant relationship $(b=0.457 * * *)$ between

TABLE 1: Reliability statistics.

\begin{tabular}{lcc}
\hline Likert scale & Cronbach's alpha & No. of items \\
\hline Output performance & 0.808 & 5 \\
Resource performance & 0.751 & 6 \\
Flexibility & 0.784 & 4 \\
\hline
\end{tabular}

HSC cooperation and output performance. The interpretation points out that cooperation's influence was significant at $99 \%$ confidence interval. This result corroborates with interview results, which noted that cooperation enabled humanitarian actors to provide shelter, clothing and basic water and sanitation as demanded by cyclone victims. One logistics officer said:

'Cooperation helped the situation in a great way; cooperation between government, humanitarian agencies and NGOs and the private sector ensured effectiveness of humanitarian efforts. We were able to reach many victims with relief goods, including tents, water containers, water purifiers, plastic sheet, tarpaulins and generators.' (Interviewee 4, male, Interviewed at Harare, 08 January 2020)

Furthermore, respondents indicated that the presence of all forms of cooperation, horizontal and vertical, along the HSC helped to identify the most critical needs. An officer with Harare-based organisation said:

'In the early days of our relief operations we relied on Econet Wireless for drones that assessed the extent of the humanitarian situation in the area. We are then able to determine what aid to deliver to the affected areas. The army went a long way in assisting us as they used their helicopters to assess need as well as deliver some of the aid to critical areas.' (Interviewee 10, male, Interviewed at Harare, 08 January 2020)

The findings concur with most empirical studies (Hedlund \& Clarke 2011; Wankumuller \& Reina 2019), recommending that because of common demand uncertainties during disaster response, different forms of cooperation implemented by responding partners and along the whole supply chain were of essence in making sure relevant goods and services were delivered.

\section{Impact of supply chain cooperation on resource performance}

Table 2 column 2 shows the impact of supply chain cooperation on cost efficiency of disaster response. Results show a significant positive relationship between HSC cooperation and cost efficiency at $1 \%$ level of significance. According to column 2 of the Table 2, $b=0.275^{* * *}$ indicate that implementation of HSC cooperation significantly improves cost efficiency. Results from interviewees support these quantitative results. They all agreed that cooperation between humanitarian actors and government officers, which included the police and the army, minimised theft and pilferage and facilitated cost efficient vehicle routing.

TABLE 2: The impact of humanitarian strategies on performance variables 1-3.

\begin{tabular}{lccc}
\hline Variables & $\begin{array}{c}\mathbf{1} \\
\text { Output } \\
\text { performance }\end{array}$ & $\begin{array}{c}\mathbf{2} \\
\text { Resource } \\
\text { performance }\end{array}$ & $\begin{array}{c}3 \\
\text { Flexibility } \\
\text { performance }\end{array}$ \\
\hline Cooperation $(b)$ & $0.457^{* * *}$ & $0.275^{* * *}$ & $0.598^{* * *}$ \\
& $(0.132)$ & $(0.0952)$ & $(0.0995)$ \\
Constant & $-3.531 *$ & -0.964 & $-5.685 * * *$ \\
& $(1.933)$ & $(1.352)$ & $(1.450)$ \\
Observations & 23 & 23 & 23 \\
$R$-squared & 0.355 & 0.186 & 0.577 \\
\hline
\end{tabular}

Note: Robust standard errors in parentheses.

Level of significance: ${ }^{* *}$, significant at $1 \%$; *, significant at $5 \%$; , significant at $10 \%$. 
Extensive cooperation led to load consolidation achieving full truck loads thereby saving on fuel. They further said that cooperation within the supply chain alleviated non-value adding practices. One of the Harare-based interviewees said:

'The operation benefited immensely from cooperation with the army and the police. They provided security to in-transit aid as well as safeguard inventory in warehouses, reducing loss through theft, which we normally experienced in other aid distribution.' (Interviewee 6, male, Interviewed at Harare, 10 January 2020)

One of the interviewees is also quoted:

'Through working together all orders within the nearest proximity were collected and consolidated, full truckloads were achieved and the final distribution of goods and services to the final beneficiaries was achieved at very low costs.' (Interviewee 9, female, Interviewed at Mutare, 22 January 2020)

The results are also consistent with previous studies (Ramalingam et al. 2013; Simatupang \& Sridharan 2015; Whipple \& Rusell 2007) that find cooperation between international actors and local NGOs achieves decreased project costs making provision of aid cheaper. The results further corroborate with Barringer and Harrison (2000) who also claim that the network and relationships will improve on time of deliveries. These results are consistent with previous studies about the response to Tsunami 2004 where responding partners duplicated the efforts of delivering too much food stuffs and clothing whilst leaving out provision of shelter and helicopter transport operations for rescue purposes.

\section{Impact of supply chain cooperation on flexibility performance}

Results shown in Table 2 column 3 indicate that cooperation had a positive and significant influence $\left(b=0.598^{* * *}\right)$ on flexibility performance in Cyclone Idai relief operations in Zimbabwe. The standard error of only $1 \%$ shows that there is a strong and significant impact of HSC cooperation on flexibility performance in relief operations. Most key informants from humanitarian actors also concurred with the given result as they all agreed that demand for some aid goods and services, during Cyclone Idai relief operation, was unforeseen and through cooperation flexibility was achieved. One key informant said:

'Sometimes demand for aid was unforeseen, because of the inaccessibility of some of the areas affected by the cyclone. When organisations first moved into Chimanimani and Chipinge, the affected areas, they were not aware of the numbers of people affected. However, with time the number of victims swelled. We worked together with other stakeholders through sharing of information and each organisation was allocated a region to operate in and were able to cope with unforeseen demand and deal with surging demand for aid.' (Interviewee 7, female, Interviewed at Mutare, 22 January 2020)

This concurred with one of the interviewees who informed that:

'Through cooperation we were able to change the amount of aid delivered as at times we were able to consolidate our consignment with other relief organisations; we were able to bring a variety of goods in response to changes in relief aid recipients' needs as each organisation would bring a product/service they specialise in; and sometimes new beneficiary needs would arise; however, organisations were able to supply the new relief items requested by the beneficiaries.' (Interviewee 8 , male, Interviewed at Chimanimani, 21 January 2020)

These results confirm the findings by Whipple and Russell (2007) that cooperation improved networks, resulting in improved delivery and customer satisfaction. This is further corroborated by Schulz and Blecken (2010) who argued for cooperation amongst humanitarian organisation to enhance supply chain flexibility.

\section{Conclusion and recommendations}

The results of this study conclude that there is a significant positive impact of humanitarian cooperation of supply chain stakeholders on flexibility, resource and output performance as evidenced by strong and significant coefficients in the results. This is also supported by qualitative responses from various interviews, which point out that cooperation in HSC management has improved coordination of activities, enhanced cost efficiency and helped to alleviate non-value adding activities.

The concept of HSC management, although it has been long born, is still largely at its infancy in developing world and has attracted few researchers in the last decade. On the theoretical aspect, the study will contribute to the body of knowledge through literature and the thematic issues that will result in principles being developed from the study. The findings of this study will enable both the government and humanitarian organisations in Zimbabwe to understand and embrace supply management practices and incorporate them in the management for their respective supply chains.

The study will also be beneficial to the humanitarian organisations in terms of planning for future disasters. The study will further provide insights into the challenges during the field of operations of both the existing and developing humanitarian organisations. The results will also be handy to the government and the people of Zimbabwe in policy formulation and decision-making to mitigate the effects of future disasters.

\section{Limitations and recommendations for future studies}

This study looks at the impact of cooperation in HSC activities on flexibility, resource and output performance in Cyclone Idai relief operations in Zimbabwe. However, the study omitted other countries that also experienced the horrible effects of Cyclone Idai. The study can be extended to other countries, Madagascar, Mozambique and Malawi, that were also hit by Cyclone Idai. Comparative case studies on interorganisational cooperation in operations in at least two of these countries may be needed. Further studies are needed on how stakeholder cooperation impacts on HSC resilience 
as resilience has become a topical issue in supply chain management.

\section{Acknowledgements}

The authors would like to acknowledge the contribution from all the respondents in this study.

\section{Competing interests}

The authors have declared that no competing interests exist.

\section{Authors' contributions}

All authors contributed equally to this work.

\section{Funding information}

The research received no specific grant from any funding agency in the public, commercial or not-for-profit sector.

\section{Data availability statement}

Data sharing is not applicable to this article as no new data were created or analysed in this study.

\section{Disclaimer}

The views and opinions expressed in this article are those of the authors and do not necessarily reflect the official policy or position of any affiliated agency of the authors.

\section{References}

Adem, S.A., Childerhouse, P., Egbelakin, T. \& Wang, B., 2018, 'International and local NGO supply chain collaboration: An investigation of the Syrian refugee crises in Jordan', Journal of Humanitarian Logistics and Supply Chain Management 8(3) 295-322. https://doi.org/10.1108/JHLSCM-05-2017-0020

Almatrooshi, B., Kumar, S.S. \& Farouk, S., 2016, 'Determinants of organizational performance: A proposed framework', International Journal of Productivity and Performance Management 65(6), 844-859. https://doi.org/10.1108/ IJPPM-02-2016-0038

Barringer, B.R. \& Harrison, J.S., 2000, 'Walking a tightrope: Creating value through inter-organisational relationship', Journal of Management 26(3), 367-403. https://doi.org/10.1177/014920630002600302

Beamon, B.M., 1999, 'Measuring supply chain performance', International Journal of Operations \& Production Management 19(3), 275-292. https://doi. org/10.1108/01443579910249714

Beamon, B.M. \& Balcik, B., 2008, 'Performance measure in humanitarian relief chains January 2008', International Journal of Public Sector Management 21(1):4-25. https://doi.org/10.1108/09513550810846087.

Brown, K. \& Keast, R., 2003, 'Citizen-government engagement: Community connection through networked arrangements', Asian Journal of Public Administration 25(1) 107-132. https://doi.org/10.1080/02598272.2003.10800411

Bryman, A., 2012, 'How many qualitative interviews is enough?', in S.E. Baker \& R. Edwards (eds.), How many qualitative interviews is enough? Expert voices and early career reflections on sampling and cases in qualitative research, pp. 18-20, ESRC National Centre for Research Methods, University of Southampton, Southampton.

Chandes, J. \& Paché, G., 2019, 'Strategizing humanitarian logistics: The challenge of collective action', Problems and Perspectives in Management 8(1), 99-107.

Chari, F. \& Ngcamu, B.S., 2017, 'The impact of collaborative strategies on disaster risk reduction in Zimbabwe dairy supply chains in 2016', The Journal for
Transdisciplinary Research in Southern Africa 13(1), a433. https://doi. org/10.4102/td.v13i1.433

Chari, F., Ngcamu, B.S. \& Novukela, C., 2020, 'Supply chain risks in humanitarian relief operations: A case of Cyclone Idai relief efforts in Zimbabwe', Journal of Humanitarian Logistics and Supply Chain Management 11(1), 29-45. https://doi. org/10.1108/JHLSCM-12-2019-0080

European Commission, 2019, European civil protection and humanitarian aid operations: Southern Africa and Indian Ocean, viewed 15 May 2020, from https:// ec.europa.eu/echo/where/africa/southern-africa_en

Fritz Institute, 2005, Humanitarian logistics conference 2005, viewed 22 April 2020, from http://www.fritzinstitute.org/prgSC-HLC2005-proceedings.htm
Government of India, 2009, National policy on disaster management. National Disaster Management Authority, viewed 08 April 2020, from https://nidm.gov.in/ PDF/policies/ndm_policy2009.pdf.

Hedlund, K. \& Knox Clarke, P., 2011, Drought related emergencies, ALNAP lessons paper, ALNAP/Overseas Development Institute (ODI), London.

Herrmann, J., 2007, Disaster response planning \& preparedness: Phases of disaster NYDIS manual for New York City religious leaders: Spiritual care and mental health for disaster response and recover, pp. 11-14, New York Disaster Interfaith Services (affiliate of the National Disaster Interfaiths Network), New York, NY.

Heale, R. \& Twycross, A., 2015, 'Validity and reliability in quantitative research', Evidence-Based Nursing 18(3), 66-67.

Iyer, K., 2011, 'Demand chain collaboration and operational performance: Role of IT analytic capability and environmental uncertainty', Journal of Business and Industrial Marketing 26(2), 81-91. https://doi.org/10.1108/08858621111112267

Kamalahmadi, M. \& Mellat-Parast, M., 2016, 'Developing a resilient supply chain through supplier flexibility and reliability assessment', International Journal of Production Research 54(1), 302-321. https://doi.org/10.1080/00207543.2015.1088971

Kapucu, N., 2006, 'Interagency communication networks during emergencies', The American Review of Public Administration 36(2), 207-225. https://doi. org/10.1177/0275074005280605

Kovacs, G. \& Spens, K.M., 2017, 'Humanitarian logistics in disaster relief operations', International Journal of Physical Distribution and Logistics Management 37(2), 99-114. https://doi.org/10.1108/09600030710734820

Lambe, C.J., Wittmann, C.M. \& Spekman, R.E., 2001, 'Social exchange theory and research on business-to-business relational exchange', Journal of Business-toBusiness Marketing 8(3), 1-36. https://doi.org/10.1300/J033v08n03_01

Majewski, B., Boulet-Desbareau, P., Slezak, M., De Meulder, F. \& Wilson, K., 2012, Joint strategic evaluation of the global logistics clusterm, World Food Programme (WFP) Food, Rome.

Martin, C., 2016, Logistics and supply chain management, 5th edn., Prentice Hall, New York, NY.

McMaster, R. \& Baber, C., 2012, 'Multi-agency operations: Cooperation during flooding', Applied Ergonomics 43(1), 38-47. https://doi.org/10.1016/j. apergo.2011.03.006

Mhlanga, C., Muzingili, T. \& Mpambela, M., 2019, 'Natural disasters in Zimbabwe: The primer for social work intervention', African Journal of Social Work 9(1), 46-54.

Muntaka, A.S., Haruna, A. \& Mensah, H.K., 2017, 'Supply chain integration and flexibility and its impact on business performance', International Journal of Business and Management 12(4), 130-143. https://doi.org/10.5539/ijbm. v12n4p130

Mushanyuri, B.E. \& Ngcamu, B.S., 2020, 'The effectiveness of humanitarian supply chain management in Zimbabwe', Journal of Transport and Supply Chain Management 14, a505. https://doi.org/10.4102/jtscm.v14i0.505

Narasimhan, R. \& Jayaram, J., 1998, 'Causal linkage in supply chain management: An exploration study of North American manufacturing companies', Decision Sciences 29(3), 579-605. https://doi.org/10.1111/j.1540-5915.1998.tb01355.x

Neely, A., Gregory, M. \& Platts, K., 1995, 'Performance measurement systems design: A literature review and research agenda', International Journal of Operations and A literature review and research agenda', International Journal of Operations and
Productions Management 15(4), 80-116. org/10.1108/01443579510083622

Nolte, I.M. \& Boenigk, S., 2013, 'A study of Ad Hoc network performance in disaster response', Nonprofit and Voluntary Sector Quarterly 42(1), 148-173. https://doi. response', Nonprofit and Voluntary
$\mathrm{org} / 10.1177 / 0899764011434557$

Ödlund, A., 2010, 'Pulling the same way? A multi-perspectivist study of crisis cooperation in government', Journal of Contingencies and Crisis Management 18(2), 96-107. https://doi.org/10.1111/j.1468-5973.2010.00605.x

Pai, F.Y. \& Yeh, T.M., 2015, 'The effects of interdependence and cooperative behaviors on buyer's satisfaction in the semiconductor component supply chain' Sustainability 8(1), 2. https://doi.org/10.3390/su8010002

Pettit, S.J. \& Baresford, A.K.C., 2009, 'Critical Success Factors in the Context of Humanitarian aid supply chains', International Journal of Physical Distribution \& Logistics Management 39(6), 450-468. https://doi. org/10.1108/09600030910985811

Polit, D.F., Beck, C.T. \& Hungler, B.P., 2001, Essentials of Nursing Research: Methods, Appraisal and Utilization, 5th edn., Lippincott Williams \& Wilkins, Philadelphia.

Ramalingam, B., Gray, B. \& Cerruti, G., 2013, Missed opportunities: The case for strengthening national and local partnership-based humanitarian responses, viewed 23 April 2020, from https://www.alnap.org/help-library/missedopportunities-the-case-for-strengthening-national-and-local-partnership-based.

Save the Children, 2019, 2019: Climate shocks claim more than 1200 lives across east and southern Africa, viewed 11 August 2020, from https://www.savethechildren. net/news/2019-climate-shocks-claim-more-1200-lives-across-east-andnet/news/2019-c
southern-africa.

Schulz, S.F. \& Blecken, A., 2010, 'Horizontal cooperation in disaster relief logistics: Benefits and impediments', International Journal of Physical Distribution \& Logistics Management 40(8/9), 636-656. https://doi.org/10.1108/09600031011079300

Sekaran, U. \& Bougie, R., 2016, Research methods for business: A skill building approach, 7th edn., Wiley, Chichester.

Simatupang, T. \& Sridharan, R., 2015, 'The Collaborative Supply Chain', The International Journal of Logistics Management 13(1), 15-30.

Tatham, P.H. \& Pettit, S.J., 2010, 'Transforming humanitarian logistics: The journey to supply network management', International Journal of Physical Distribution and Logistics Management 40(8), 609-622. https://doi. org/10.1108/09600031011079283 
Taylor-Powell, E. \& Renner, M., 2003, Analyzing Qualitative Data, University of Wisconsin-Extension, Madison.

The Government Office for Science, 2012, Foresight reducing risks of future disasters: Priorities for decision makers (2012), The Government Office for Science, Final project report, London.

UNICEF, 2019, Zimbabwe humanitarian situation report no. 7, 31 May, IOM 2019, Zimbabwe Cyclone Idai response: Situation report 29, May 8-14, 2019, UN Children's Fund, Harare.

Van Wassenhove, L.N., 2006, 'Humanitarian aid logistics: Supply chain management in high gear', Journal of the Operational Research Society 57(5), 475-489. https:// doi.org/10.1057/palgrave.jors.2602125
Walliman, N., 2011, Research methods: The basics, 1st edn., Routledge, ISBN: 9780415489942, London.

Wankmüller, C. \& Reiner, G., 2020, 'Coordination, cooperation and collaboration in relief supply chain management', Journal of Business Economics 90, 239-276. https://doi.org/10.1007/s11573-019-00945-2

Wankmuller, C. \& Reiner, G., 2019, 'Coordination, cooperation and collaboration in relief supply chain management', Journal of Business Economics 90, 239-276. https://doi.org/10.1007/s11573-019-00945-2

Whipple, J.M. \& Russell, D., 2007, 'Building supply chain collaboration: A typology of collaborative approaches', The International Journal of Logistics Management 18(2), 174-196. https://doi.org/10.1108/09574090710816922 


\section{Appendix 1}

\section{Questionnaire}

Section A: To what extent did your organisation rely on the following supply chain cooperation strategies in Cyclone Idai response?

\begin{tabular}{|c|c|c|c|c|c|}
\hline \multicolumn{6}{|c|}{ Section A: Humanitarian supply chain cooperation strategies } \\
\hline 1. Resource and information sharing & 1 & 2 & 3 & 4 & 5 \\
\hline 2. Conducting joint projects & 1 & 2 & 3 & 4 & 5 \\
\hline 3. Geographical division of tasks & 1 & 2 & 3 & 4 & 5 \\
\hline $\begin{array}{l}\text { 4. Cluster-based division of tasks (water, health, } \\
\text { education ...) }\end{array}$ & 1 & 2 & 3 & 4 & 5 \\
\hline 5. Centralised decision-making & 1 & 2 & 3 & 4 & 5 \\
\hline
\end{tabular}

1 , not at all; 2 , to a small extent; 3 , to some extent; 4 , to a moderate extent; 5 , to a great extent.

Section B: Indicate the extent to which cooperation amongst humanitarian actors has affected the achievement of output performance in Cyclone Idai relief operations in Zimbabwe. Please use the following scale to answer the given questions: 1, not at all; 2, to a small extent; 3 , to some extent; 4 , to a moderate extent; 5 , to a great extent

\begin{tabular}{llllll}
\hline Section B: Output performance & & & & & \\
\hline 1. Deliver the right supplies & 1 & 2 & 3 & 4 & 5 \\
2. Poverty alleviation/decrease human suffering & 1 & 2 & 3 & 4 & 5 \\
3. Restore community normalcy & 1 & 2 & 3 & 4 & 5 \\
4. Achieve resilience & 1 & 2 & 3 & 4 & 5 \\
5. Save lives & 1 & 2 & 3 & 4 & 5 \\
\hline
\end{tabular}

Section C: Indicate the extent to which cooperation amongst humanitarian actors has affected the achievement of resource performance in Cyclone Idai relief operations in Zimbabwe. Please use the following scale to answer the given questions: 1, not at all; 2, to a small extent; 3 , to some extent; 4 , to a moderate extent; 5 , to a great extent.

\begin{tabular}{|c|c|c|c|c|c|}
\hline Section C: Resource performance & & & & & \\
\hline 1. Reduced cost of supplies & 1 & 2 & 3 & 4 & 5 \\
\hline 2. Reduced distribution costs & 1 & 2 & 3 & 4 & 5 \\
\hline 3. Reduced inventory holding costs & 1 & 2 & 3 & 4 & 5 \\
\hline 4. Reduced the number of workers per aid recipient & 1 & 2 & 3 & 4 & 5 \\
\hline $\begin{array}{l}\text { 5. Reduced the number of hours spent serving an aid } \\
\text { recipient }\end{array}$ & 1 & 2 & 3 & 4 & 5 \\
\hline 6. Reduced the total dollars spent per aid recipient & 1 & 2 & 3 & 4 & 5 \\
\hline
\end{tabular}

Section D: Indicate the extent to which cooperation amongst humanitarian actors has affected the achievement of flexibility performance in Cyclone Idai relief operations in Zimbabwe. Please use the following scale to answer the given questions: 1, not at all; 2, to a small extent; 3, to some extent; 4 , to a moderate extent; 5 , to a great extent.

\begin{tabular}{|c|c|c|c|c|c|}
\hline \multicolumn{6}{|l|}{ Section D: Flexibility performance } \\
\hline 1. Ability to respond changes in volume of aid demanded & 1 & 2 & 3 & 4 & 5 \\
\hline 2. Ability to respond to changes in delivery times & 1 & 2 & 3 & 4 & 5 \\
\hline $\begin{array}{l}\text { 3. Ability to respond to changes in variety of aid } \\
\text { demanded }\end{array}$ & 1 & 2 & 3 & 4 & 5 \\
\hline $\begin{array}{l}\text { 4. Ability to introduce new products to meet the needs } \\
\text { of disaster victims }\end{array}$ & 1 & 2 & 3 & 4 & 5 \\
\hline
\end{tabular}

\section{Interview guide}

1. What cooperation strategies did you rely on in mitigating humanitarian supply chain risk in delivery relief aid to Cyclone Idai victims? 


\section{Probe:}

- Resource and information sharing

- Conducting joint projects

- Cluster-based division of tasks

- Geographical division of tasks

- Centralised decision-making

\section{Performance}

How effective was each of the humanitarian supply chain management cooperation forms that you employed in achieving your intervention objectives of output, flexibility and resource performance in Cyclone Idai?

\section{Probe:}

a. Output performance

- Deliver the right supplies

- Decrease human suffering

- Restore community normalcy

- Achieve resilience

- Save lives

b. Flexibility performance

- Ability to respond to changes in volume of aid demanded

- Ability to respond to changes in delivery times

- Ability to respond to changes in variety of combination of aid demanded

- Ability to introduce new products to the needs of disaster victims

C. Resource performance

- Reduced cost of supplies

- Reduced distribution costs

- Reduced inventory holding costs

- Reduced the number of workers per aid recipient

- Reduced the number of hours spent serving an aid recipient

- Reduced the total dollars spent per aid recipient.

\section{The End}

